\title{
(-)-Complanine, an inflammatory substance of marine fireworm: a synthetic study
}

\author{
Kazuhiko Nakamura ${ }^{*}, 1$, Yu Tachikawa ${ }^{2}$ and Daisuke Uemura ${ }^{*}, 1,2$
}

\section{Preliminary Communication}

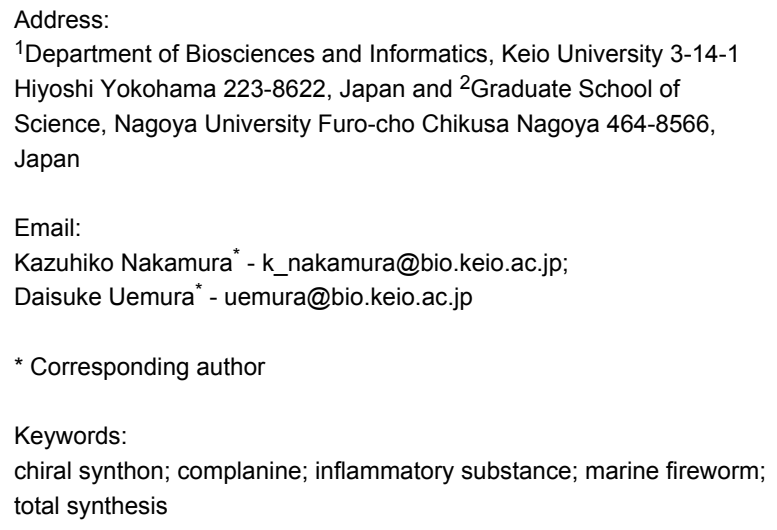

Beilstein Journal of Organic Chemistry 2009, 5, No. 12 doi:10.3762/bjoc. 5.12

Received: 03 March 2009

Accepted: 09 April 2009

Published: 16 April 2009

Editor-in-Chief: J. Clayden

(C) 2009 Nakamura et al; licensee Beilstein-Institut. License and terms: see end of document.

\section{Abstract}

The synthesis of (-)-complanine, an inflammatory substance of Eurythoe complanata, was accomplished by a "chiral synthon" approach. The absolute configuration of this molecule was determined to be $R$.

\section{Introduction}

Toxic marine annelids were first referred to in the literature as "sea scolopendra" in de Materia Medica (A.D. 50) by Dioscorides, a physician of the Roman Empire [1]. The marine animals, which are commonly known as "fireworms", are dangerous to humans, as careless handling with bare hands can result in serious dermatitis. However the actual toxic substance of these animals has remained unknown. We recently isolated a novel amphipathic substance, named complanine (Figure 1), from an amphinomid polychaete, Eurythoe complanata (Figure 2). Complanine has been identified as an inflammatory substance by bioassay-guided separations; and the substance is thought to be used as part of the animal's defense system. In a previous study the molecular mechanism of inflammation by the action of complanine was examined, and its activation of protein kinase $\mathrm{C}$ (PKC) in the presence of $\mathrm{Ca}^{2+}$ and 12-O-tetradecanoylphorbol 13-acetate (TPA) has been proved. These results suggest that complanine can bind $\mathrm{PKC}$ at the same site as phosphatidylserine, a co-activation factor with $\mathrm{Ca}^{2+}$ and TPA. It is known that signal transduction leads to an inflammation mediator TNF- $\alpha$ and its downstream signal molecules, which occurs by phosphorylation through the action of PKC;

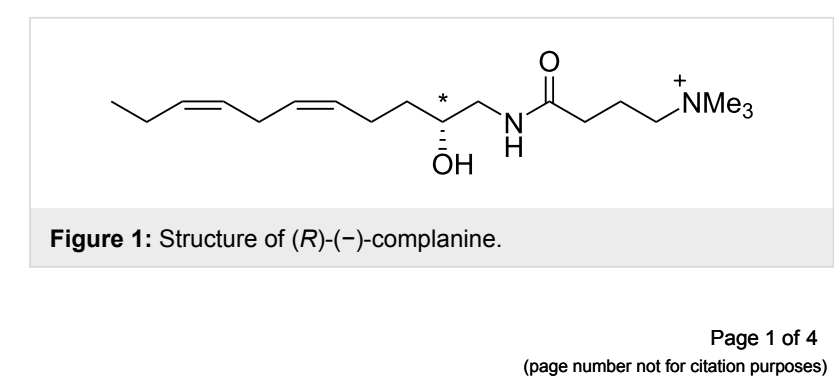




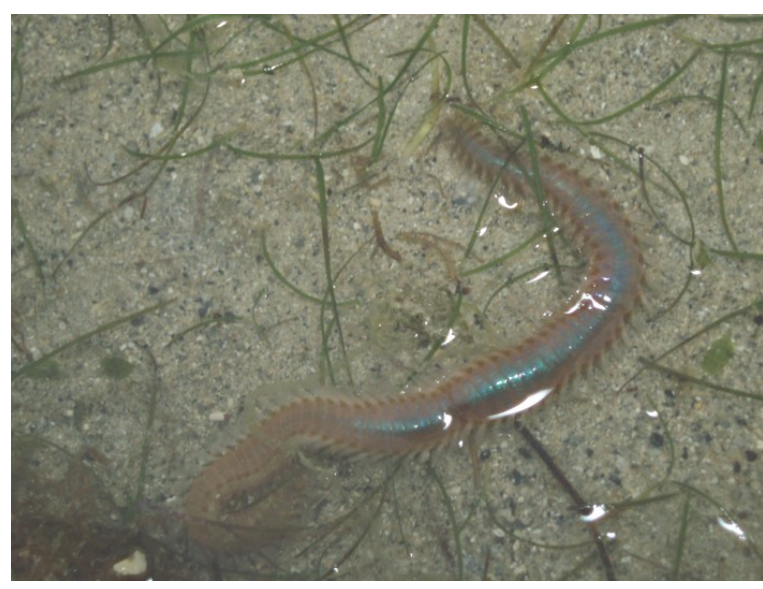

Figure 2: Marine fireworm Eurythoe complanata (body length $10 \mathrm{~cm}$ ).

thus, the biological properties of complanine can be understood as controlling this cascade [2].

From a structural perspective, complanine possesses amphipathic properties due to its characteristic unsaturated carbon chain and a $\gamma$-aminobutyric acid (GABA)-derived trimethylammonium substructure. Natural complanine shows negative optical rotation $\left([\alpha]_{\mathrm{D}}{ }^{25}=-10.0\left(c 1.0, \mathrm{H}_{2} \mathrm{O}\right)\right)$, but the configuration of the hydroxy-substituted carbon atom has not been revealed because derivatization to determine the absolute configuration failed due to the lack of availability of the natural product. In this study, the absolute structure of complanine was unambiguously determined by means of synthetic methodology by a "chiral synthon" approach. Related amino alcohols possessing olefins from marine natural resources have been identified $[3,4]$, but synthetic studies of these compounds have not been reported.

\section{Results and Discussion}

Our synthesis started from the known compound 3 [5,6] that could be derived from $(R)$-malic acid, $(R)$-2, in three steps (1. $\mathrm{BH}_{3} \cdot \mathrm{SMe}_{2} ; 2$. cat. TsOH, $\mathrm{Et}_{2} \mathrm{CO} ; 3$. TsCl, pyridine) (Scheme 1). The resultant tosylate 3 was treated with lithium acetylide ethylenediamine complex to give the terminal acetylene 4 in $51 \%$ yield [7]. The bromomagnesium salt of 4 generated with $\mathrm{EtMgBr}$ was successively treated with 1-iodopent-2-yne in the presence of $\mathrm{CuI}$ to give the corresponding diyne compound $\mathbf{5}$ in $43 \%$ yield [8]. The partial reduction was achieved by using Lindlar catalyst to give the desired $Z$ olefin, which was then subjected to acidic deprotection to afford the diol 6 in $43 \%$ yield ( 2 steps). The primary alcohol was converted into the azide via the mesylate (79\%), which was then successfully converted into the corresponding amino alcohol 7 (78\%). From a spectral perspective, the amino alcohol 7 was identical to the degradation product of natural complanine (NMR, MS and $R_{f}$ value of TLC).

The activated ester (hydroxysuccinimide ester) of 4-(trimethylammonio)butanoate was synthesized from the commercially

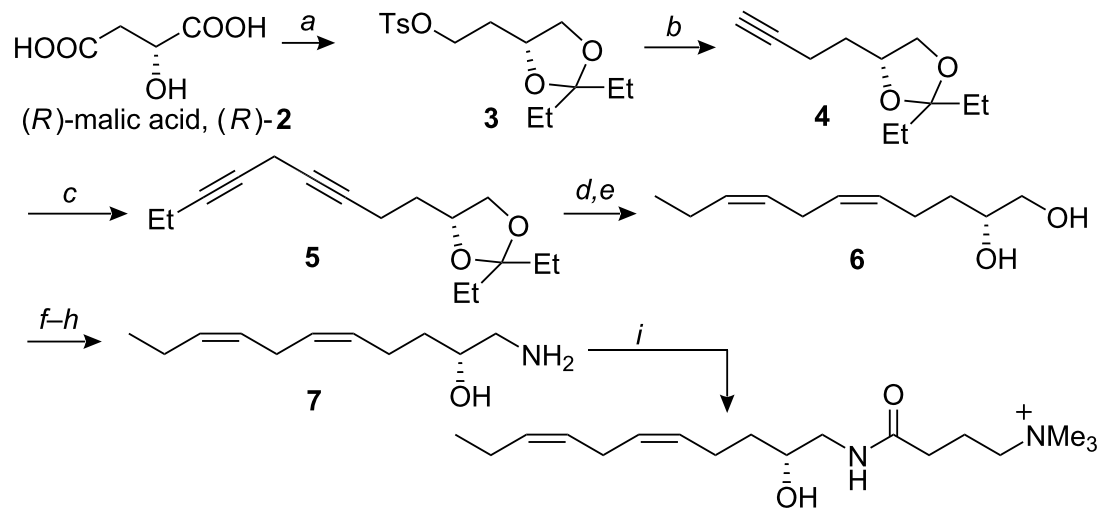

(R)-1 (natural complanine)

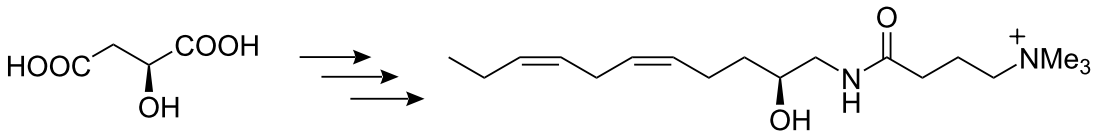

(S)-2

(S)-1 (ent-complanine)

Scheme 1: Total synthesis of complanine. Keys: a) 1. $\mathrm{BH}_{3} \cdot \mathrm{SMe}_{2}(71 \%) ; 2$. cat. TsOH, $\mathrm{Et}_{2} \mathrm{CO}(59 \%) ; 3$. TsCl, pyridine (80\%) [5,6]; $\left.b\right)$ lithium acetylide ethylenediamine complex (1.2 equiv), DMSO, rt, $3 \mathrm{~h}(51 \%) ; c)$-iodopent-2-yne (2.0 equiv), $\mathrm{EtMgBr}\left(1.6\right.$ equiv), Cul (cat.), THF, $0{ }^{\circ} \mathrm{C}$ to rt, $12 \mathrm{~h}$ $(43 \%)$; d) $\mathrm{H}_{2}$, Lindlar catalyst, $\left.\mathrm{EtOH}, \mathrm{rt}, 30 \mathrm{~min} ; \mathrm{e}\right) \mathrm{AcOH}, \mathrm{H}_{2} \mathrm{O}, \mathrm{rt}, 12 \mathrm{~h}\left(43 \%\right.$ in 2 steps); f) $\mathrm{MsCl}\left(1.1\right.$ equiv), $\left.\mathrm{pyridine} \mathrm{CH}_{2} \mathrm{Cl}_{2}, 0{ }^{\circ} \mathrm{C}, 2 \mathrm{~h} ; g\right) \mathrm{NaN}_{3}(4.0$ equiv), DMF, $80{ }^{\circ} \mathrm{C}, 11 \mathrm{~h}(79 \%$ in 2 steps); $h) \mathrm{PPh}_{3}$ (1.0 equiv), THF, $\left.\mathrm{H}_{2} \mathrm{O}, \mathrm{rt}, 12 \mathrm{~h}(78 \%) ; i\right) \mathrm{N}$-[4-(trimethylammonio)butyryloxy]succinimide iodide (see text and [9]) (2.0 equiv), $\mathrm{MeOH}, \mathrm{rt}, 18 \mathrm{~h}(44 \%)$. 
available $\gamma$-aminobutyric acid (GABA) in two steps (1. MeI, $\mathrm{NaHCO}_{3}, \mathrm{MeOH}, \mathrm{rt}, 24 \mathrm{~h} ; 2$. HOSu; DCC, $\mathrm{CH}_{3} \mathrm{CN}, \mathrm{rt}, 24 \mathrm{~h}$ ) [9]. A reaction occurred between the amino alcohol and the activated ester (2.0 equiv) in $\mathrm{MeOH}$ to give the desired (-)complanine in $44 \%$ yield. The synthesized product was identical to the natural material in all its spectral data, including optical rotation $\left([\alpha]_{\mathrm{D}}{ }^{20}=-9.9\left(c 0.12, \mathrm{H}_{2} \mathrm{O}\right)\right)$. The configuration of the hydroxy-substituted carbon atom was determined to be $R$. The configuration is comparable to that of the related compound, obscuraminol, isolated from an ascidian from Tarifa Island, Spain. Obscuraminol possesses a vic-amino alcohol and an unsaturated carbon chain; its absolute configuration (of the $\mathrm{OH}$ adjacent carbon atom) is $R$ [4]. The similarity of the structures suggests a close relationship in their biosynthetic pathways. It can be hypothesized that complanine is biosynthesized from glycine, based on comparison with serine- or alaninederived natural products $[3,4,10,11]$.

The enantiomer of the natural product, $(+)$-complanine, was also successfully synthesized from the corresponding $(S)$-malic acid, $(S)$-2, in 10 steps, including coupling with 4-(trimethylammonio)butanoate. $(S)$-1 (ent-complanine) showed positive optical rotation $\left([\alpha]_{\mathrm{D}}{ }^{23}=11.1\left(c 0.65, \mathrm{H}_{2} \mathrm{O}\right)\right)$; which was in reasonably good agreement with the absolute configuration of the natural product. The biological activities of both enantiomers were examined, but no significant difference between them was observed based on the inflammatory activity on a mouse foot pad. Detailed biological properties (for example, $\mathrm{PKC}$ activation) of both enantiomers are under consideration at the present time.

In conclusion, (-)-complanine was successfully synthesized from $(R)$-malic acid by acetylene coupling and catalytic hydrogenation as key steps. The absolute configuration of the natural product was determined to be $R$.

\section{Experimental}

Synthesis of alkyne 4: To a solution of tosylate $(3,3.00 \mathrm{~g}, 9.1$ $\mathrm{mmol})$ in DMSO $(10 \mathrm{ml})$, a lithium acetylide ethylene diamine complex (1.00 g, $11.0 \mathrm{mmol})$ was added under nitrogen atmosphere. After stirring for $3 \mathrm{~h}$, an extractive workup and column chromatography $\left(\mathrm{SiO}_{2}\right.$, hexane/ethyl acetate $\left.99: 1\right)$ gave the desired alkyne 4 as a pale yellow oil $(850 \mathrm{mg}, 51 \%) .4:[\alpha]_{\mathrm{D}}{ }^{26}$ +2.1 (c 1.0, $\left.\mathrm{CHCl}_{3}\right)$; HRMS (ESI) calcd for $\mathrm{C}_{11} \mathrm{H}_{18} \mathrm{O}_{2} \mathrm{Na}[(\mathrm{M}+$ $\left.\mathrm{Na})^{+}\right]$205.1204, found 205.1201; ${ }^{1} \mathrm{H}$ NMR $\left(400 \mathrm{MHz}, \mathrm{CDCl}_{3}\right)$ $\delta 4.14(1 \mathrm{H}, \mathrm{m}), 4.04(1 \mathrm{H}, \mathrm{dd}, J=6.2,7.6 \mathrm{~Hz}), 3.48(1 \mathrm{H}, \mathrm{t}, J=$ $7.6 \mathrm{~Hz}), 2.27(2 \mathrm{H}, \mathrm{m}), 1.91(1 \mathrm{H}, \mathrm{t}, J=2.8 \mathrm{~Hz}), 1.78(1 \mathrm{H}, \mathrm{m})$, $1.69(1 \mathrm{H}, \mathrm{m}), 1.57(4 \mathrm{H}, \mathrm{m}), 0.84(3 \mathrm{H}+3 \mathrm{H}, \mathrm{t}, J=7.6 \mathrm{~Hz}$, overlapped).
Synthesis of diyne 5: To a solution of the alkyne (4, $445 \mathrm{mg}$, $2.45 \mathrm{mmol})$ in THF $(2.0 \mathrm{ml}), 1.6 \mathrm{M}$ solution of ethylmagnesium bromide (Aldrich, $2.45 \mathrm{ml}, 3.92 \mathrm{mmol}$ ) was added under $\mathrm{N}_{2}$, and the resulting solution was stirred at ambient temperature. After $15 \mathrm{~min}$, copper(I) iodide $(2.0 \mathrm{mg}$, catalytic) was added, and the solution was stirred for additional $12 \mathrm{~h}$. The solution was cooled to $0{ }^{\circ} \mathrm{C}$, and 1-iodopent-2-yne (950 mg, $4.90 \mathrm{mmol}$ ) was added to the reaction mixture and gradually warmed to room temperature. After stirring for $12 \mathrm{~h}$, an extractive workup and column chromatography $\left(\mathrm{SiO}_{2}\right.$, hexane/ ethyl acetate $98: 2$ to $95: 5)$ gave the desired diyne compound 5 as a pale yellow oil $(258 \mathrm{mg}, 43 \%)$. 5: $[\alpha]_{\mathrm{D}}{ }^{26}+2.7(c 0.26$, $\mathrm{CHCl}_{3}$ ); HRMS (ESI) calcd for $\mathrm{C}_{16} \mathrm{H}_{24} \mathrm{O}_{2} \mathrm{Na}\left[(\mathrm{M}+\mathrm{Na})^{+}\right]$ 271.1674, found 271.1696; ${ }^{1} \mathrm{H}$ NMR $\left(600 \mathrm{MHz}, \mathrm{CDCl}_{3}\right) \delta 4.17$ $(1 \mathrm{H}, \mathrm{m}), 4.09(1 \mathrm{H}, \mathrm{dd}, J=6.0,7.6 \mathrm{~Hz}), 3.52(1 \mathrm{H}, \mathrm{dd}, J=7.6$, $7.6 \mathrm{~Hz}), 3.11(2 \mathrm{H}, \mathrm{t}, J=2.2 \mathrm{~Hz}), 2.29(2 \mathrm{H}, \mathrm{m}), 2.17(2 \mathrm{H}, \mathrm{m})$, $1.80(1 \mathrm{H}, \mathrm{m}), 1.69(1 \mathrm{H}, \mathrm{m}), 1.62(4 \mathrm{H}, \mathrm{m}), 1.12(3 \mathrm{H}, \mathrm{t}, J=7.6$ $\mathrm{Hz}), 0.89(3 \mathrm{H}+3 \mathrm{H}, \mathrm{t}, J=7.4 \mathrm{~Hz}$, overlapped $)$.

Synthesis of diol 6: To the solution of the diyne 5 (103 mg, $0.410 \mathrm{mmol})$ in ethanol $(4.0 \mathrm{ml})$, Lindlar catalyst $(206 \mathrm{mg})$ was added. The mixture was stirred under hydrogen atmosphere for $30 \mathrm{~min}$. After filtration of the catalyst, the concentrated residue was dissolved in an $\mathrm{AcOH} / \mathrm{H}_{2} \mathrm{O}(4.0: 3.5 \mathrm{ml})$ mixture and then stirred for $13 \mathrm{~h}$. The concentrated residue was subjected to column chromatography $\left(\mathrm{SiO}_{2}\right.$, hexane/ethyl acetate $\left.1: 1\right)$ to give the desired diol 6 as a colorless oil. 6: $[\alpha]_{\mathrm{D}}{ }^{20}-2.0(c 0.40$, $\mathrm{CHCl}_{3}$ ); HRMS (ESI) calcd for $\mathrm{C}_{11} \mathrm{H}_{20} \mathrm{O}_{2} \mathrm{Na}\left[(\mathrm{M}+\mathrm{Na})^{+}\right]$ 207.1361, found 207.1346; ${ }^{1} \mathrm{H}$ NMR (600 MHz, $\left.\mathrm{CD}_{3} \mathrm{OD}\right) \delta$ 5.24-5.35 (4H, m), 3.53 (1H, br, s), $3.41(2 \mathrm{H}, \mathrm{m}), 2.77$ (2H, t, $J$ $=5.2 \mathrm{~Hz}), 2.17(1 \mathrm{H}, \mathrm{m}), 2.12(1 \mathrm{H}, \mathrm{m}), 2.03(2 \mathrm{H}, \mathrm{m}), 1.50(1 \mathrm{H}$, m), $1.39(1 \mathrm{H}, \mathrm{m}), 0.92(3 \mathrm{H}, \mathrm{t}, J=7.7 \mathrm{~Hz}) ;{ }^{13} \mathrm{C} \mathrm{NMR}\left(\mathrm{CD}_{3} \mathrm{OD}\right)$ $\delta 132.6,130.4,129.6,128.4,72.7,67.4,34.4,26.4,24.3$ 21.4, 14.6 .

Synthesis of amino alcohol 7 via an azide: To the solution of the diol $(6,16.2 \mathrm{mg}, 88 \mu \mathrm{mol})$ in dichloromethane $(2.0 \mathrm{ml})$, pyridine $(1.2 \mathrm{ml})$ and mesyl chloride $(11.1 \mathrm{mg}, 97 \mu \mathrm{mol})$ were added. After stirring for $2 \mathrm{~h}$, the extractive workup was carried out to give a colorless oil $(24.2 \mathrm{mg})$. This crude material was successively dissolved in DMF $(0.4 \mathrm{ml})$, and sodium azide (23 $\mathrm{mg}, 330 \mu \mathrm{mol})$ was then added. The reaction mixture was maintained at $80^{\circ} \mathrm{C}$ for $11 \mathrm{~h}$. An extractive workup and preparative TLC $\left(\mathrm{SiO}_{2}\right.$, ethyl acetate) gave the desired azide as a colorless oil (14.6 mg, $79 \%$ in 2 steps). IR $\left(\mathrm{CHCl}_{3}\right): 2105 \mathrm{~cm}^{-1}$.

The solution of the resultant azide $(14.6 \mathrm{mg}, 70 \mu \mathrm{mol})$ in THF $(1.0 \mathrm{ml}), \mathrm{H}_{2} \mathrm{O}(25 \mu \mathrm{l})$ and triphenylphosphane $(18.3 \mathrm{mg}, 70$ $\mu \mathrm{mol})$ were added. After stirring for $12 \mathrm{~h}$, the reaction mixture was concentrated, and the desired product $(10.0 \mathrm{mg}, 78 \%)$ was obtained by chromatography on $\mathrm{SiO}_{2}$ (eluent: $\mathrm{CHCl}_{3} / \mathrm{MeOH}$ / 
$\left.\mathrm{H}_{2} \mathrm{O} 10: 5: 1\right)$ as a colorless oil. 7: HRMS (ESI) calcd for $\mathrm{C}_{11} \mathrm{H}_{22} \mathrm{NO}\left[(\mathrm{M}+\mathrm{H})^{+}\right]$184.1701, found 184.1707; ${ }^{1} \mathrm{H}$ NMR $\left(600 \mathrm{MHz}, \mathrm{CD}_{3} \mathrm{OD}\right) \delta 5.25-5.37(4 \mathrm{H}$, br m), $3.75(1 \mathrm{H}$, br s), $2.96(1 \mathrm{H}, \mathrm{dd}, J=3.1,12.4 \mathrm{~Hz}), 2.79(2 \mathrm{H}, \mathrm{t}, J=6.6 \mathrm{~Hz}), 2.73$ $(1 \mathrm{H}, \mathrm{dd}, J=9.6,12.4 \mathrm{~Hz}), 2.23(1 \mathrm{H}, \mathrm{m}), 2.16(1 \mathrm{H}, \mathrm{m}), 2.06$ $(2 \mathrm{H}, \mathrm{m}), 1.49(2 \mathrm{H}, \mathrm{m}), 0.95(3 \mathrm{H}, \mathrm{t}, J=7.6 \mathrm{~Hz}) ;{ }^{13} \mathrm{C} \mathrm{NMR}(150$ $\left.\mathrm{MHz}, \mathrm{CD}_{3} \mathrm{OD}\right) \delta 131.4,129.0,128.3,127.0,71.4,46.9,34.5$, 25.0, 23.0, 20.1, 13.3.

Synthesis of $(\boldsymbol{R})$-complanine, $(\boldsymbol{R})$-1: To the solution of the amino alcohol $7(1.8 \mathrm{mg}, 9.9 \mu \mathrm{mol})$ in $\mathrm{MeOH}(150 \mu \mathrm{l}), N$-[4(trimethylammonio)butyryloxy] succinimide iodide [9] $(5.5 \mathrm{mg}$ $20 \mathrm{mmol})$ in $\mathrm{MeOH}(150 \mu \mathrm{l})$ was added. The reaction mixture was stirred for $18 \mathrm{~h}$. The resultant mixture was concentrated, and the residue was purified by column chromatography $\left(\mathrm{SiO}_{2}\right.$, $\left.\mathrm{CHCl}_{3} / \mathrm{MeOH} / \mathrm{H}_{2} \mathrm{O} / \mathrm{AcOH} 10: 5: 1: 0.06\right)$ to give the synthetic complanine (1.4 mg, 44\%) as a colorless oil. $(R)-1$ (synthetic complanine): HRMS (ESI) calcd for $\mathrm{C}_{18} \mathrm{H}_{35} \mathrm{~N}_{2} \mathrm{O}_{2}{ }^{+}$ $\left[(\mathrm{M})^{+}\right]$311.2693, found 311.2698; $[\alpha]_{\mathrm{D}}{ }^{20}=-9.9\left(c 0.12, \mathrm{H}_{2} \mathrm{O}\right)$; ${ }^{1} \mathrm{H}$ NMR $\left(600 \mathrm{MHz}, \mathrm{D}_{2} \mathrm{O}\right) \delta 5.31-5.37(4 \mathrm{H}$, br m), $3.64(1 \mathrm{H}, \mathrm{br}$ m), $3.22(2 \mathrm{H}+1 \mathrm{H}, \mathrm{m}), 3.09(1 \mathrm{H}, \mathrm{dd}, J=6.9,13.8 \mathrm{~Hz}), 3.02$ $(9 \mathrm{H}, \mathrm{s}), 2.43(2 \mathrm{H}, \mathrm{t}, J=6.5 \mathrm{~Hz}), 2.28(2 \mathrm{H}, \mathrm{t}, J=7.6 \mathrm{~Hz}), 2.08$ $(2 \mathrm{H}, \mathrm{m}), 1.98(2 \mathrm{H}, \mathrm{m}), 1.41(2 \mathrm{H}, \mathrm{m}), 0.84(3 \mathrm{H}, \mathrm{t}, J=7.6 \mathrm{~Hz})$; ${ }^{13} \mathrm{C}$ NMR $\left(150 \mathrm{MHz}, \mathrm{D}_{2} \mathrm{O}\right) \delta 180.9,174.3,129.6,129.1,127.6$, 69.5, 65.5, 52.9 (3C), 45.9, 33.8, 31.7, 25.2, 23.3, 20.2, 18.8, 13.8 .

Synthesis of $(S)$-complanine, $(S)$-1: The enantiomer of natural complanine was also synthesized from $(S)$-malic acid. $(S)$-1 (ent-complanine): $[\alpha]_{\mathrm{D}}{ }^{23}=11.1\left(c 0.65, \mathrm{H}_{2} \mathrm{O}\right)$.

\section{Acknowledgments}

The authors are thankful for the financial support from a Grantin-Aid for the Creative Scientific Research program of the Ministry of Education, Science, Culture, and Sports of Japan.

\section{References}

1. Halstead, B. W. Poisonous and Venomous Marine Animals of the World; United States Government Printing Office: Washington, DC, 1965; Vol. 1, pp 895-906.

2. Nakamura, K.; Tachikawa, Y.; Kitamura, M.; Ohno, O.; Suganuma, M.; Uemura, D. Org. Biomol. Chem. 2008, 6, 2058-2060. doi:10.1039/b803107j

3. Clark, R. J.; Garson, M. J.; Hooper, J. N. A. J. Nat. Prod. 2001, 64, 1568-1571. doi:10.1021/np010246x

4. Garrido, L.; Zubía, E.; Ortega, M. J.; Naranjo, S.; Salvá, J. Tetrahedron 2001, 57, 4579-4588. doi:10.1016/S0040-4020(01)00372-6

5. Hanessian, S.; Ugolini, A.; Dubé, D.; Glamyan, A. Can. J. Chem. 1984, 62, 2146-2147. doi:10.1139/v84-367

6. Börjesson, L.; Csöregh, I.; Welch, C. J. J. Org. Chem. 1995, 60, 2989-2999. doi:10.1021/jo00115a013

7. Koert, U.; Stein, M.; Wagner, H. Chem.-Eur. J. 1997, 3, 1170-1180. doi:10.1002/chem.19970030723
8. Langille, N. F.; Jamison, T. F. Org. Lett. 2006, 8, 3761-3764. doi:10.1021/ol0613721

9. Mirzaei, H.; Regnier, F. Anal. Chem. 2006, 78, 4175-4183. doi:10.1021/ac0602266

10. Brady, R. N.; Di Mari, S. J.; Snell, E. E. J. Biol. Chem. 1969, 244, 491-496.

11. Kobayashi, J.-i.; Ishibashi, M. Heterocycles 1996, 42, 943-970. doi:10.3987/REV-95-SR6

\section{License and Terms}

This is an Open Access article under the terms of the Creative Commons Attribution License

(http://creativecommons.org/licenses/by/2.0), which permits unrestricted use, distribution, and reproduction in any medium, provided the original work is properly cited.

The license is subject to the Beilstein Journal of Organic Chemistry terms and conditions: (http://www.beilstein-journals.org/bjoc)

The definitive version of this article is the electronic one which can be found at: doi:10.3762/bjoc.5.12 